\title{
NUTRITIONAL VALUE OF RAW PORK DEPENDING ON THE FAT TYPE CONTENTS IN PIGS FEED
}

\author{
Bożena Waszkiewicz-Robak ${ }^{\bowtie}$, Arkadiusz Szterk, Mateusz Rogalski, \\ Michał Rambuszek, Monika Kruk, Ewelina Rokowska \\ Department of Functional, Organic Food and Commodities, Warsaw University of Life Sciences - SGGW \\ Nowoursynowska 159 C, 02-787 Warsaw, Poland
}

\begin{abstract}
Background. The research aimed to assess the nutritional value of raw pork meat obtained from pigs on the feed containing different types of used fat.

Material and methods. Meat was obtained from pigs fed in 4 experimental groups, from which groups $\mathrm{A}$ and $\mathrm{B}$ were given the mixture of rapeseed oil and linseed oil in the ratio of 1:2.5 or 2.3:1:0.2 (lard) as the source of fat. In group C, animals were given the mixture of rapeseed oil (1 part), fish oil (cod-liver oil; 2 parts) and lard (0.5 part), whereas group D obtained the mixture of linseed oil in the same ratio as in group B (2.5 parts), but combined with cod-liver oil (1 part). Meat collected for the research was evaluated and underwent chemical analyses in order to determine its nutritional value. The contents of moisture, protein, fat and ash were determined according to the AOAC methods. The carbohydrate content in various samples was determined by subtracting the sum of moisture, protein, ash and fat content from 100. Energy value (EV) was calculated using Atwater factors. The fatty acids content were analysed in homogenized samples using Folch method. Methyl esters of fatty acids were separated by gas chromatography on GC Trace Ultra THERMO company equipped with a RT 2560 RESTEC capillary column $(100 \mathrm{~m} \times 0.25 \mathrm{~mm} \times 0.2 \mu \mathrm{m})$ with helium as a carrier gas.

Result. The modification of the source of fat in pigs feed did not influence the content of protein and total minerals (ash), whereas it significantly influenced the content of fat and moisture. It has been stated that the use of different fat type in pigs feed, contributed to receiving the meat with modified profile of fatty acids. Higher fatty acids of the n-3 was observed in groups B and D (treated with the mixture of oils with a predominance of linseed oil). The fat from the meat of these groups contain less of n- 6 and n-9 fatty acid, which improved the quality indicator of the fat expressed as the ratio of n- $6 / n-3$. Meat obtained from animals of the groups contained significantly less MUFA, and comparable content UFA and SFA. The meat from all experimental groups the ratio of polyunsaturated fatty acids (PUFA), saturated fatty acids (SFA) remained at a similar level and was 0.5:0.6.

Conclusions. The modification of the source of fat in pigs feed did not influence the content of protein and total minerals (ash), whereas it significantly influenced the content of fat and moisture. A different source of fat in pigs feed did not influence the content of fat, saturated fatty acids (SFA) and UFA (unsaturated fatty acids) in fat, whereas it significantly influenced the participation of particular fatty acids belonging to monounsaturated (MUFA) and n-3 and n-6 groups.
\end{abstract}

Key words: pork meat, nutritional value, fat type in pigs feed

\footnotetext{
区b_robak@wp.pl 


\section{INTRODUCTION}

The global production of meat (beef, pork, poultry, as well as mutton and goat) increased significantly between 1962-1964 and 2001-2003. The global production of pork has exceeded the production of beef since 1980-1982 and was $57.6 \%$ higher than that of beef in 2001-2003. It is assumed that production and consumption of meat will probably continue to increase and probably by 2020 it will have amounted to 300 million metrictonnes (MT) compared to 233 million MT in 2000 (FAO, 2008). Simultaneously, the increasing percentage of the population falling sick with diet-dependent diseases associated with high meat consumption has been observed. In the prevention of these diseases a great attention is paid to the content of fatty acids in the diet, particularly from n-3 PUFA group, since it has been proven that their proper supply decreases thrombotic disposition, which in turn lowers the risk of coronary heart disease or atherosclerosis in humans (Department of Health, 1994).

The deficiency of n-3 PUFA fatty acids in the diet, or the wrong ratio of $n-6$ to $n-3$ acids might lead to brain disorders and mental ill-health, age-related maculopathy (ARM), Alzheimer's disease, schizophrenia or Huntington's disease (FAO, 2008).

According to the experts of International Society for the Study of Fatty Acids and Lipids (Ntawubizi et al., 2010), the ratio of n-6 PUFA to n-3 PUFA acids in the diet should be lower than 4 , whereas the nutrition standards state that the proper ratio of n- 6 to $n-3$ polyunsaturated fatty acids in a daily food ration should range from 6:1 to 4:1 (FAO, 2008).

Concerns regarding the health of the society force decision-makers and food producers to obtain various raw materials, including materials of animal origin, of the highest quality and nutritional value, being simultaneously the source of ingredients counteracting or impeding the development of diet-dependent diseases. The possibility of shaping the content of fatty acids in pork meat is one of such solutions. Although the quality of pork meat depends on many factors, including environmental (slaughter weight, age on slaughter day, upkeep conditions) and genetic (race, cross-breeding schemes, gender), the modification of fatty acid profile in meat through specific animal feed seems to be a relatively easy way (Kouba and Mourot, 2011).
Among various species of breeding animals, the research on the modification of the profile of fatty acids in meat was conducted on rabbits (Peiretti, 2012), sheep (Cooper et al., 2004), pigs (Barowicz and Kędzior, 2000; Ntawubizi et al., 2010), or poultry (Sirri et al., 2011). Published research in this scope is varied, therefore, hard to compare, since it discusses the ways of feeding animals of different races or genetic lines (Fiego et al., 2005; Grześkowiak et al., 2010), different developmental age (Więcek et al., 2011), or given feed with varied additives supplying $n-3$ fatty acids.

Polyunsaturated fatty acids cannot be synthetized in the body of pigs, therefore, they need to be supplied in the feed in the dominating form, i.e. linoleic acid and $\alpha$-linolenic (Cooper et al., 2004). Good effects are obtained through the enrichment of pigs feed with three acids: $\alpha$-linolenic acid (18:3 n-3), eicosapentaenoic acid (20:5 n-3) and docosahexaenoic acid (22:6 n-3) (Wachira et al., 2002). Another way is the use of various kinds of fat of high n-3 fatty acid participation, e.g. vegetable oils (linseed oil, soybean oil, rapeseed oil) (Cooper et al., 2004). Good effects in shaping the profile of fatty acids both in muscular, intramuscular, as well as covering fat are obtained with the use of various vegetable oils or vegetable materials such as spirulina (Spirulina platensis), curcuma (Curcuma longa), tomato (Lycopersicon esculentum Mill.) pomace, perilla (Perilla frutescens), golden flaxseed (Linum usitatissimum L.) (Peiretti, 2012), chia seed (Salvia hispanica L.) (Coates and Ayerza, 2009), or rapeseed expellers (Hanczakowska, 2006) in the feed of breeding animals.

The research aimed to assess the nutritional value of raw pork obtained from pigs given the feed with supplemented with the mixture of rapeseed, linseed and fish oils and possibly lard.

\section{MATERIAL AND METHODS}

Meat from pigs on standard feed, differing with the type of added fat was used in the research. The research was conducted in 4 experimental groups (Table 1).

Studies were conducted on 32 crossbred pigs, progeny of a Duroc boar and eight half-sisters (Polish Large White $\times$ Danish Landrace). The animals came from one boar and related mothers. The animals were 
Table 1. Feed components in experimental groups

\begin{tabular}{|c|c|c|c|c|}
\hline \multirow{2}{*}{$\begin{array}{c}\text { Feed components } \\
\mathrm{g} \cdot \mathrm{kg}^{-1} \text { of feed }\end{array}$} & \multicolumn{4}{|c|}{ Experimental group - a mixture of oils in the feed } \\
\hline & A & $\mathrm{B}$ & $\mathrm{C}$ & $\mathrm{D}$ \\
\hline Barley grits & 360 & 360 & 360 & 360 \\
\hline Wheat middlings & 360 & 360 & 360 & 360 \\
\hline Corn grits & 100 & 100 & 100 & 100 \\
\hline Extracted rapeseed meal & 40 & 40 & 40 & 40 \\
\hline Extracted soybean meal & 80 & 80 & 80 & 80 \\
\hline Premix vitamin-minerals & 25 & 25 & 25 & 25 \\
\hline Rapeseed oil & 25 & 10 & 10 & - \\
\hline Linseed oil & 10 & 23 & - & 25 \\
\hline Fish oil (cod-liver oil) & - & - & 20 & 10 \\
\hline Lard & - & 2 & 5 & - \\
\hline
\end{tabular}

Diets: $\mathbf{A}-2.5 \%$ rapeseed oil and $1 \%$ linseed oil; $\mathbf{B}-2.3 \%$ linseed oil, $1 \%$ rapeseed oil $+0.2 \%$ lard; C $-1 \%$ rapeseed oil, $2 \%$ fish oil $+0.5 \%$ lard; $\mathbf{D}=2.5 \%$ linseed oil and $1 \%$ fish oil.

Premix as $2.5 \%$ of the diet provided the required amount of micro- and macrominerals, essential amino acids, and vitamins ( $\alpha$-tocopherol $240 \mathrm{mg} / \mathrm{kg}$ of feed; on the basis of Lisiak et al. (2013)).

maintained individually in pens equipped with automatic feeders and nipple drinkers, in the pigsty of the Institute of Animal Physiology and Nutrition in the Polish Academy of Sciences in Jabłonna near Warsaw, under the same thermo-neutral conditions: air temperature $18-20^{\circ} \mathrm{C}$, humidity $60-70 \%$, and the air speed $0.2-4 \mathrm{~m} / \mathrm{s}$. The animals were slaughtered at the BW of about $105 \mathrm{~kg}$, using the same slaughter technology (electrical stunning, bleeding in a hanging position, cooling by the single-degree method) (on the basis of Lisiak et al., 2013). A particular content of feed, type and mutual proportions of added oils was presented in Table 1 and 2.

This experiment was carried out under the Project Biofood parallel in different academic units, including: Warsaw University of Life Sciences, Department of Meat and Fat Technology, Institute of Agricultural and Food Biotechnology, Poznań, Poland and in The Kielanowski Institute of Animal Nutrition and Physiology, Polish Academy of Sciences, Jabłonna, Poland. The research material was from the same experiment. Chemical composition, nutritive value of compound feed, and fatty acids concentration of the diets described in Lisiak et al. (2013) - Table 2.

The material came from cooled semi-carcass and was collected 24 hours after slaughter. $\mathrm{H}_{24}$ was measured and in each case it amounted to $>5.5$. Based on this as well as visual color evaluation, ranging from light pink to red, it has been established that material was free of qualitative deficiency of PSE and DFD type (Lisiak et al., 2013). Culinary part - neck was taken from each left carcass in group $(n=8)$. Pork steak weighing from 100 to $150 \mathrm{~g}$ was cut out for the nutritional evaluation.

\section{MEASUREMENTS AND ANALYTICAL METHODS}

The nutritional value. The contents of moisture, protein, fat and ash were determined according to the AOAC (1990). The carbohydrate content in various samples was determined by subtracting the sum of moisture, protein, ash and fat content from 100. Energy value (EV) was calculated using Atwater factors. 
Table 2. Chemical composition and fatty acids concentration of the diets (Lisiak et al., 2013)

\begin{tabular}{lcccc}
\hline \multirow{2}{*}{$\begin{array}{c}\text { Chemical components and } \\
\text { fatty acids concentration } \\
\mathrm{g} \cdot \mathrm{kg}^{-1} \text { of feed }\end{array}$} & \multicolumn{4}{c}{ Experimental group - a mixture of oils in the feed } \\
\cline { 2 - 5 } & 892 & 886 & 889 & 887 \\
\hline Dry matter & 172 & 165 & 167 & 166 \\
Crude protein & 61 & 59 & 62 & 64 \\
Ether extract & 40 & 43 & 43 & 41 \\
Crude fibre & 460 & 450 & 453 & 440 \\
Starch & 84 & 87 & 83 & 88 \\
Sugar & 133 & 133 & 134 & 131 \\
Digestible crude protein & 7.56 & 9.32 & 9.59 & 9.51 \\
$\Sigma$ SFA & 17.42 & 15.12 & 16.74 & 15.14 \\
$\Sigma$ MUFA & 24.71 & 27.95 & 23.63 & 28.68 \\
$\Sigma$ PUFA & 19.58 & 19.31 & 19.58 & 18.22 \\
LA C18:2 n-6 & 5.13 & 8.51 & 2.30 & 9.98 \\
ALA C18:3 n-3 & 0.00 & 0.00 & 0.01 & 0.00 \\
AA C20:4 & & & & B \\
\hline
\end{tabular}

Diets: $\mathbf{A}-2.5 \%$ rapeseed oil and $1 \%$ linseed oil; $\mathbf{B}-2.3 \%$ linseed oil, $1 \%$ rapeseed oil + $0.2 \%$ lard $\mathbf{C}-1 \%$ rapeseed oil, $2 \%$ fish oil $+0.5 \%$ lard; $\mathbf{D}=2.5 \%$ linseed oil and $1 \%$ fish oil.

Total lipid and fatty acids analysis. A sample of $0.2 \mathrm{~g}$ of fat was dissolved in $2 \mathrm{ml}$ of hexane. The mixture was submitted for saponification with $1.0 \mathrm{ml}$ of sodium hydroxide solution in methanol $(2 \mathrm{M})$ at room temperature for $20 \mathrm{~min}$. Then $200 \mu \mathrm{l}$ of the hexane layer was transferred into $1.5 \mathrm{ml}$ autosampler vial and dissolved in $1 \mathrm{ml}$ of hexane. After that, $1 \mu \mathrm{l}$ of the sample was injected into a GC-FID system (Thermo Trace Ultra GC) equipped with the RT2560 capillary column. Helium was used as the carrier gas at a constant flow rate of $0.9 \mathrm{ml} \cdot \mathrm{min}^{-1}$. A split injector was operated at a temperature of $230^{\circ} \mathrm{C}$ with a split rate set to $50: 1$. The GC oven temperature was programmed as follows: $80^{\circ} \mathrm{C}$ hold for $1 \mathrm{~min}$, ramped to $180^{\circ} \mathrm{C}$ at a rate of $3.0^{\circ} \mathrm{C} \cdot \mathrm{min}^{-1}$, hold for $3 \mathrm{~min}$ next ramped to $230^{\circ} \mathrm{C}$, at rate $6.0^{\circ} \mathrm{C} \cdot \mathrm{min}^{-1}$, hold for $3 \mathrm{~min}$. FID detector parameters: base temperature $260^{\circ} \mathrm{C}$, ignition threshold $0.5 \mathrm{pA}$, air flow $-350 \mathrm{ml} \cdot \mathrm{min}^{-1}$, hydrogen flow -35 $\mathrm{ml} \cdot \mathrm{min}^{-1}$ and makeup nitrogen flow $-25 \mathrm{ml} \cdot \mathrm{min}^{-1}$. Calculated were totals of SFAs, MUFAs, PUFAs and separately the sum of PUFA n-6 and PUFA n-3. In addition, for comparison, the index was calculated which is the ratio of n-6 to n-3.

Statistical analysis. Data were presented as means. Obtained results were statistically analysed with STATGRAPHIC programme for Windows (v. 5.1). The data was analysed using one-way analysis of variance (ANOVA). When a significant $F$ ratio was found, Tukey's multiple-comparison tests were conducted. Differences were considered significant at $\mathrm{p}<0.05$.

\section{RESULTS}

While analysing the content of essential nutrients presented in Table 3, such as protein, carbohydrates (mainly glycogen), water or ash, it was stated that the content of protein was similar and it ranged from 19.9 to $20.7 \mathrm{~g} / 100 \mathrm{~g}$ of raw meat. Similarly, total mineral content, expressed as ash (from 1.21 to $1.26 \mathrm{~g} / 100 \mathrm{~g}$ ) 
Table 3. Content of essential nutrients in raw pig meat (neck) obtained from different experimental groups

\begin{tabular}{|c|c|c|c|c|c|c|c|}
\hline \multirow{2}{*}{\multicolumn{2}{|c|}{$\begin{array}{l}\text { Experimental } \\
\text { groups - a mix- } \\
\text { ture of different } \\
\text { fats in feed }\end{array}$}} & \multicolumn{5}{|c|}{ Nutrients in $100 \mathrm{~g}$ of meat, $\mathrm{g}$} & \multirow[b]{2}{*}{$\begin{array}{c}\text { Energy value } \\
\text { kJ (kcal) }\end{array}$} \\
\hline & & protein & fat & water & ash & $\begin{array}{l}\text { carbo- } \\
\text { hydrates }\end{array}$ & \\
\hline \multicolumn{2}{|l|}{ A } & 20.4 & 7.4 & 70.9 & 1.2 & 0.1 & $624.1(148.6)$ \\
\hline \multicolumn{2}{|l|}{ B } & 20.7 & 7.6 & 70.3 & 1.3 & 0.1 & 636.7 (151.6) \\
\hline \multicolumn{2}{|l|}{$\mathrm{C}$} & 19.9 & 7.9 & 70.1 & 1.2 & 0.9 & $648.1(154.3)$ \\
\hline \multicolumn{2}{|l|}{$\mathrm{D}$} & 20.1 & 7.2 & 71.3 & 1.3 & 0.1 & $611.5(145.6)$ \\
\hline \multicolumn{2}{|l|}{ SEM } & 0.556 & 0.709 & 0.511 & 0.043 & - & 1.548 \\
\hline \multirow[t]{6}{*}{ Contrast } & $A-B$ & NS & NS & NS & NS & - & NS \\
\hline & $\mathrm{A}-\mathrm{C}$ & NS & $*$ & NS & NS & - & NS \\
\hline & $A-D$ & NS & NS & NS & NS & - & NS \\
\hline & $\mathrm{B}-\mathrm{C}$ & NS & NS & NS & NS & - & NS \\
\hline & $\mathrm{B}-\mathrm{D}$ & NS & * & * & NS & - & NS \\
\hline & $\mathrm{C}-\mathrm{D}$ & NS & $*$ & $*$ & NS & - & NS \\
\hline
\end{tabular}

A, B, C, D - rapeseed, linseed oil, fish oil and lard in diet, respectively, with the first and second letter indicating the diet in phase 1 and 2 , respectively.

* - denotes a statistically significant difference $(\mathrm{p}<0.05)$.

NS - contrasts between the 2 dietary treatments are nonsignificant $(\mathrm{p}>0.05)$.

did not differ significantly (ANOVA, $\mathrm{p}>0.05$ ). However, significant differences were observed (ANOVA, $\mathrm{p}<0.05)$ in meat from particular groups in moisture content (70.1 to $71.3 \mathrm{~g} / 100 \mathrm{~g}$ ) and fat (from 7.2 to $7.9 \%$ ) in meat from particular groups.

Tables 4 and 5 present the content of particular fatty acids and the profile of fatty acids of fat contained in pork meat, obtained from different experimental groups. Data proves that the type of fat added to pigs feed and their mutual ratio significantly influenced the content of particular fatty acids and their different groups in fat obtained from pork. In all experimental groups, pork fat contained most oleic acid C18:1n9c (29.988\% of fat from group A, $28.284 \%$ from group B, $31.160 \%$ from group C and $30.263 \%$ from group D). The content of this acid did not differ significantly in meat obtained from each group (ANOVA, $p>0.05$ ).

In the pig fat of meat from all groups, the participation of palmitic acid C16:0 (22.134-23.017\%) and stearic acid C18:0 (11.539-14.395\%) that did not differ significantly between groups was observed (Table 3). Meat from group D (fat in feed with fish oil participation) contained significantly more linoleic acid C18:2n6c (LA) $(15.506 \%$ of fat) than meat from the remaining groups (ANOVA, $p<0.05$ ). Fat from met from $\mathrm{B}$ and $\mathrm{D}$ groups had a significantly higher (ANOVA, $\mathrm{p}<0.05)$ content of $\alpha$-linolenic acid C18:3n3 (ALA) (respectively 4.571 and $4,101 \%$ of meat fat) in comparison with $2.322 \%$ of this acid in fat from $\mathrm{C}$ group and $3.524 \%$ from A group.

A similar dependence (ANOVA, $\mathrm{p}<0.05$ ), was observed in relation to eicosatrienoic acid $\mathrm{C} 20: 3 \mathrm{n} 3$, which in the fat of meat from $\mathrm{B}$ and $\mathrm{D}$ groups amounted to respectively $0.55 \%$ and $0.459 \%$, from A group - to significantly less, i.e. $0.385 \%$ and from group C $-0.459 \%$. From a nutritional point of view, a significantly higher ratio of eicosapentaenoic acid C20:5n 3 (EPA) in the fat from meat from B and D groups in relations to meat from groups $\mathrm{A}$ and $\mathrm{C}$ is very advantageous. The participation of docosahexaenoic acid 
Table 4. Fatty acid profile in raw pork (neck) obtained from the different experimental groups, $\%$ fat

\begin{tabular}{|c|c|c|c|c|c|}
\hline \multirow{2}{*}{ The fatty acid } & \multicolumn{4}{|c|}{$\begin{array}{l}\text { Experimental groups - different source of fat in feed } \\
\qquad \% \text { composition }\end{array}$} & \multirow{2}{*}{$\begin{array}{l}\text { Overall treatmen } \\
\text { significance }\end{array}$} \\
\hline & A & $\mathrm{B}$ & $\mathrm{C}$ & $\mathrm{D}$ & \\
\hline C4:0 Butyric & $0.071 \mathrm{a}$ & 0.063 & 0.052 & 0.059 & NS \\
\hline C6:0 Caproic & 0.088 & 0.044 & 0.031 & 0.037 & NS \\
\hline C8:0 Caprylic & 0.346 & 0.109 & 0.107 & 0.148 & NS \\
\hline C10:0 Capric & 0.214 & 0.221 & 0.251 & 0.198 & NS \\
\hline C11:0 Undecanoic & 0.126 & 0.035 & 0.023 & 0.023 & NS \\
\hline C12:0 Lauric & 0.179 & 0.117 & 0.137 & 0.167 & NS \\
\hline C13:0 Tridecanoic & 0.042 & 0.057 & 0.025 & 0.025 & NS \\
\hline C14:0 Myristic & $1.888^{*}$ & 2.235 & 2.078 & 2.056 & $* / \mathrm{p}<0.05$ \\
\hline C14:1 Myristoleic & $0.125^{*}$ & $0.096 * *$ & 0.063 & 0.086 & $* / \mathrm{p}<0.05$ \\
\hline C15:0 Pentadecanoic & 0.16 & 0.141 & $0.092 *$ & 0.115 & $* / \mathrm{p}<0.05$ \\
\hline C15:1 cis-10-Pentadecanoic & 0.002 & 0.005 & 0.004 & 0.003 & NS \\
\hline C16:0 Palmitic & 22.134 & 22.451 & 23.017 & 22.336 & NS \\
\hline 16:1n-9 Palmitoleic & 1.462 & 1.367 & $1.771 *$ & $1.577^{*}$ & $* / \mathrm{p}<0,05$ \\
\hline C17:0 Heptadecanoic & $0.744 *$ & 0.39 & 0.38 & 0.37 & $* / \mathrm{p}<0,05$ \\
\hline C17:1 cis-10-Heptadecenoic & $0.107 *$ & 0.026 & 0.017 & 0.012 & $* / \mathrm{p}<0,05$ \\
\hline C18:0 Stearic & 11.539 & 14.298 & 14.395 & 14.086 & NS \\
\hline $\mathrm{C} 18: \ln 9 \mathrm{t}$ trans & 0.251 & 0.18 & 0.186 & 0.209 & $* / \mathrm{p}<0.05$ \\
\hline C18:1n9c Oleic & 29.988 & 28.284 & 31.16 & 30.263 & NS \\
\hline C18:2n6t Stearic & $0.18^{*}$ & 0.056 & 0.031 & 0.055 & $* / \mathrm{p}<0.05$ \\
\hline C20:0 Arachidic & 0.241 & 0.082 & 0.082 & 0.086 & $* / \mathrm{p}<0.05$ \\
\hline C18:2n6c Linoleic (LA) & 17.06 & 16.842 & 16.572 & $15.506^{*}$ & $* / \mathrm{p}<0.05$ \\
\hline C18:3n6 Gamma-Linolenic & $0.285^{*}$ & $0.163 * *$ & 0.179 & 0.207 & $* / \mathrm{p}<0.05$ \\
\hline C20:1 Eicosenoic & 1.08 & 0.873 & 1.203 & 1.145 & NS \\
\hline C18:3n3 Alfa-linolenic (ALA) & $3.524 *$ & $4.571 * *$ & 2.322 & $4.101^{*}$ & $* / \mathrm{p}<0.05$ \\
\hline C21:0 Henicosanoic & 0.032 & 0.035 & 0.036 & 0.028 & NS \\
\hline C20:2 Eicosedienoic & 0.759 & 0.872 & 0.831 & 0.863 & NS \\
\hline C22:0 Arachidic & 0.013 & 0.04 & 0.037 & 0.06 & NS \\
\hline C20:3n6 Eicosatrienoic & 0.372 & 0.234 & $0.21 *$ & $0.232 *$ & NS \\
\hline C22:1n9 Arachidic & $0.265^{*}$ & 0.071 & 0.085 & 0.146 & $* / \mathrm{p}<0.05$ \\
\hline C20:3n3 Eicosatrienoic & $0.385^{* * *}$ & $0.55^{*}$ & 0.277 & $0.459 * *$ & $* / \mathrm{p}<0.05$ \\
\hline C20:4n6 Arachidonic & $0.403^{*}$ & 0.263 & 0.216 & 0.215 & $* / \mathrm{p}<0.05$ \\
\hline C23:0 Tricosanoic & $0.24 *$ & 0.058 & 0.049 & 0.054 & $* / \mathrm{p}<0.05$ \\
\hline C22:2 Docosadienoic & $0.28^{*}$ & 0.077 & 0.04 & 0.108 & $* / \mathrm{p}<0.05$ \\
\hline C24:0 Nervonic & $0.229^{*}$ & 0.051 & 0.022 & 0.068 & $* / \mathrm{p}<0.05$ \\
\hline C20:5n3 Eicosapentaenoic (EPA) & $0.097 * * *$ & $0.117 *$ & $0.056^{* *}$ & $0.12 *$ & $* / \mathrm{p}<0.05$ \\
\hline C24:1 Nervonic & $0.218^{*}$ & 0.104 & 0.083 & 0.112 & $* / \mathrm{p}<0.05$ \\
\hline C22:6n3 Docosahexaenoic (DHA) & 0.249 & 0.276 & $0.654^{*}$ & $0.629 *$ & $* / p<0.05$ \\
\hline $\begin{array}{l}\text { Percentage of identified fatty acids } \\
\text { (\% of fat) }\end{array}$ & 95.28 & 95.62 & 96.68 & 95.94 & \\
\hline
\end{tabular}

*Denotes a statistically significant difference $(\mathrm{p}<0.05)$.

NS - contrasts between the 2 or 4 dietary treatments are nonsignificant $(\mathrm{p}>0.05)$. 
Waszkiewicz-Robak, B., Szterk, A., Rogalski, M., Rambuszek, M., Kruk, M., Rokowska, E. (2015). Nutritional value of raw pork depending on the fat type contents in pigs feed. Acta Sci. Pol. Technol. Aliment., 14(2), 153-163. DOI: 10.17306/J.AFS.2015.2.17

Table 5. Content of different groups of fatty acids in adipose tissue of raw pork, $\mathrm{g} / 100 \mathrm{~g}$

\begin{tabular}{|c|c|c|c|c|c|c|c|c|c|c|c|}
\hline \multirow{2}{*}{$\begin{array}{l}\text { Groups of } \\
\text { fatty acids }\end{array}$} & \multicolumn{4}{|c|}{ Experimental groups } & \multirow{2}{*}{ SEM } & \multicolumn{6}{|c|}{ Contrast } \\
\hline & A & $\mathrm{B}$ & $\mathrm{C}$ & $\mathrm{D}$ & & A-B & A-C & A-D & $\mathrm{B}-\mathrm{C}$ & B-D & C-D \\
\hline SFA & 38.29 & 40.43 & 40.81 & 39.92 & 0.098 & NS & NS & NS & NS & NS & NS \\
\hline UFA & 56.84 & 54.85 & 55.77 & 55.84 & 0.052 & NS & NS & NS & NS & NS & NS \\
\hline MUFA & 33.25 & 30.83 & 34.39 & 33.34 & 1.119 & $*$ & $*$ & NS & $*$ & $*$ & $*$ \\
\hline Total PUFA & 23.59 & 24.02 & 21.39 & 22.50 & 0.589 & $*$ & $*$ & $*$ & * & $*$ & $*$ \\
\hline n-3 PUFA & 4.26 & 5.51 & 3.31 & 5.31 & 0.677 & $*$ & $*$ & $*$ & $*$ & NS & $*$ \\
\hline n-6 PUFA & 18.10 & 17.76 & 17.11 & 16.22 & 0.510 & NS & $*$ & $*$ & NS & * & $*$ \\
\hline n-9 PUFA & 30.50 & 28.54 & 31.43 & 30.62 & 0.383 & $*$ & $*$ & NS & $*$ & $*$ & $*$ \\
\hline$n-6 / n-3$ & 4.3 & 3.2 & 5.2 & 3.1 & 0.167 & $*$ & $*$ & $*$ & $*$ & NS & $*$ \\
\hline PUFA : SFA & 0.6 & 0.6 & 0.5 & 0.6 & - & NS & NS & NS & NS & NS & NS \\
\hline LA : ALA & 4.8 & 3.7 & 7.1 & 3.8 & - & $*$ & $*$ & $*$ & $*$ & NS & * \\
\hline
\end{tabular}

SFA - saturated fatty acids $(\mathrm{C} 14: 0+\mathrm{C} 16: 0+\mathrm{C} 18: 0)$.

UFA - unsaturated fatty acids (MUFA + total PUFA).

MUFA - monounsaturated fatty acids (C16:1n-9 + C18:1n-9 + C18:1n-7 + C20:1n-9).

Total PUFA - C18:2n-6 + C18:3n-3 + C20:3n-6 + C20:4n-6 + C20:5n-3 + C22:4n-6 + C22:5n-3 + C22:6n-3.

n-3 PUFA $-\Sigma$ n-3 fatty acids - C18:3n-3 + C20:5n-3 + C22:5n-3 + C22:6n-3.

n-6 PUFA $-\Sigma$ n- 6 fatty acids - C18:2n-6 + C20:3n-6 + C20:4n-6 + C22:4n-6.

$\mathrm{P}: \mathrm{S}$ - total PUFA-to-saturated fatty acid ratio.

Within a row, means without a common superscript letter differ $(\mathrm{P}<0.05)$.

C22:6n3 (DHA) in the fat from A $(0.249 \%)$ and B $(0.276 \%)$ groups was significantly lower than in $\mathrm{C}$ $(0.654 \%)$ and $\mathrm{D}(0.528 \%)$ groups (ANOVA, $\mathrm{p}<0.05)$.

Table 5 presents the total content of fatty acids: saturated fatty acids (SFA), unsaturated fatty acids (UFA), monounsaturated fatty acids (MUFA) and polyunsaturated fatty acids (PUFA).

The content of n-3, n- 6 and n-9 fatty acids was also presented. In meat from all experimental groups non-significantly varied content of saturated fatty acids (SFA) and unsaturated fatty acids (UFA) was observed. The sum of saturated fatty acids (SFA) constituted from 38.29 to $40.81 \%$ of fat of examined meat and did not differ significantly in all groups (ANOVA, $p>0.05$ ), whereas unsaturated fatty acids (UFA) amounted to $54.85-56.84 \%$ of fat (ANOVA, $\mathrm{p}>0.05$ ). Significantly more acids from n-6 PUFA were observed in adipose tissue of meat from A, B and $\mathrm{C}$ groups (respectively $18.10 ; 17.76$ and $17.11 \%$ ) in relation to $16.22 \%$ in D group, but simultaneously, most n-3 PUFA fatty acids group were observed in meat from B and D groups (respectively 5.51 and $5.31 \%)$.

Total number of saturated fatty acids (SFA) and unsaturated fatty acids (UFA) did not change significantly statistically (ANOVA, $p>0.05$ ). However, the ratio of particular groups (e.g. n-3, n-6 and n-9 PUFA) and particular fatty acids changed significantly. The ratio of linoleic acid (LA) to $\alpha$-linolenic acid (ALA) content did not differ significantly in B and D groups and totaled respectively 3.7 and 3.8, whereas it was significantly highest in $\mathrm{C}$ group (7.1), i.e. in meat obtained from animals on feed with lard additive (ANOVA, $p<0.05$ ). The ratio of $n-6$ PUFA to $n-3$ PUFA is the most often compared indicator influencing the nutritional value of pork fat. This indicator is similar to meat from B and D groups (respectively 3.2:1 and $3.1: 1)$, and it was significantly lower $(p<0.05)$ than in $\mathrm{A}$ and $\mathrm{C}$ groups (respectively 4.3 and 5.2:1). Very often the content of fatty acids is interpreted based 
on the ratio of polyunsaturated fatty acids PUFA to saturated fatty acids SFA. In case of the experiment conducted in this work, the ratio was similar for meat from all experimental groups and amounted to $0.5-$ $-0.6: 1$ (ANOVA, $\mathrm{p}>0.05$ ).

\section{DISCUSSION}

The results of the research presented in this work confirm the possibility of increasing the participation of n-3 polyunsaturated fatty acids (both $\alpha$-linolenic acid, as well as EPA and DHA) in pork through the use of the mixture of appropriate oils, as a source of fat in pigs feed.

The content of ALA acid in the fat of pork varied and depended on the way of feeding to a great extent. In the research by Guillevic et al. (2009), a significant influence of extruded linseed additive to pigs feed on ALA content in longissimus dorsi meat, which amounted to $2.28 \%$ of total pool of fatty acids, was observed, whereas in control group supplemented with sunflower oil it amounted only to $0.42 \%$. Nurenberg et al. (2005) showed that in the meat of pigs receiving 5\% linseed oil additive, the level of $\alpha$-linolenic acid (ALA) in total pool of fatty acids may amount to even $8.5 \%$ (hogs) and $9.1 \%$ (sows), i.e. significantly more in comparison with control group (with $5 \%$ olive oil additive), in which this value totalled respectively $0.6 \%$ (hogs) and $0.7 \%$ (sows).

Literature data regarding the influence of fat type of pigs feed on the level of EPA and DHA in meat shows that their highest accumulation in meat is observed when fish oil or seaweed preparations are added to the feed of pigs (Caceres et al., 2008; Haak et al., 2008; Sardi et al., 2006). Data concerning the influence of linseed oil or linseed is inconclusive. The research by Lu et al. (2008) did not show the influence of animal diet supplementation on the content of both EPA and DHA; in works by Huang et al. (2008); Corino et al. (2008) and Pieszka (2007) the increase in the level of both EPA and DHA was observed, whereas in the research by Juárez et al. (2010), Realini et al. (2010), Guillevic et al. (2009) and Haak et al. (2008), the increase in the level of EPA without significant influence on DHA level was noted. These differences may result both from different type of fat used in feed and the level of its additive. $\alpha$-linolenic acid - EPA and DHA precursor is supplied to the pigs' body when linseed oil or linseed rich in n-3 acids is used as a source of fat. In the feed containing high level of n-6 fatty acids in relation to the content of $\alpha$-linolenic acid (ALA), the process of bioconversion to EPA and DHA may be inhibited as a result of enzyme rivalry in the elongation cycle and denaturation (Juárez et al., 2010).

This work showed that the use of the mixture of rapeseed and linseed oil in feed with predominant share of linseed oil resulted in deposition of comparable numbers of EPA and DHA acids, like in case of supplementation of animal feed with the mixture of linseed and fish oil in the ratio of 2.5:1. Similar results were also obtained by Kowalska et al. (2011), who conducted experiments on rabbit meat.

In works by different authors on pig genotype or different ways of obtaining pork, a very different ratio of n-6 PUFA to n-3 PUFA was observed. In fat of meat of pigs consuming the mixture with flax seed oil or linseed, the ratio o n-6 PUFA to n-3 PUFA may range from even 1.6 to 3.57 (Barowicz and Kędzior, 2000; Grześkowiak et al., 2008), i.e. was more advantageous than obtained in this work, which in B and D groups amounted to around 3.2:1 and 3.1:1, and in A group to 4.3:1 and $C$ group to 5.2:1. As the research shows, the ratio of n- 6 to n-3 acids in pork oscillates within quite wide boundaries and depends on the feed content used in animal feeding. It is particularly high in meat obtained from pigs intensively fed on feed concentrations based on grains and oleaginous plants rich in linoleic acid C18:2n-6 (LA). Research by Guillevic et al. (2009) proved that it amounted to 16.75 in the Longissimus dorsi muscle of pigs on diet rich in LA (with sunflower oil additive), whereas in group receiving the additive of extruded linseed it decreased to 3.93. Corino et al. (2008) showed that 5\% extruded linseed additive to pigs feed decreased the ratio of $n-6$ to $n-3$ in meat from 12:1 (control group) to $5: 1$.

Based on the evidence and conceptual limitation, there is no rational explanation for a specific recommendation for $\mathrm{n}-6$ to $\mathrm{n}-3$ ratio, or LA to ALA ratio, if intakes of n-6 and n-3 fatty acids lie within the recommendation established in the report of an expert consultation, which is given from 3 to $4: 1$. 


\section{CONCLUSIONS}

The use of proper mixture of oils as the source of fatty acids in pigs feed allows to obtain meat of increased pro-health attributes, expressed as significantly higher content of n-3 fatty acids, advantageous, similar to nutritional recommendations rate of n-6 PUFA to $n-3$ PUFA, at comparable content of such ingredients as protein, cholesterol, vitamins and minerals. Among examined mixtures of oils, the most advantageous ratio o n-6 to n-3 fatty acids in meat amounting to about $3: 1$ was obtained with the use of rapeseed, linseed oil and the maximum $(0.2 \%)$ addition of lard in the ratio of 1:2.3:0.2 and linseed and fish oil in the ratio of 2.5:1.

Taking into consideration both nutritional value of raw meat obtained from animals on feed with oil additive, it is recommended to use the mixture of rapeseed and linseed oils, with significant predominance of linseed oil in the ratio of 1:2.5 in pigs feeding.

\section{ACKNOWLEDGMENTS}

Meat obtained from the Biofood Project (POIG.01.01. 02-014-090/09), and the tests were performed at the Department of Functional, Organic Food and Commodity, in its activity Laboratory of Food Assessment and Health Diagnostic.

\section{REFERENCES}

AOAC (1990). Official methods of analysis. Arlington: Association of Official Analytical Chemists.

Barowicz, T., Kędzior, W. (2000). Wykorzystanie pełnotłustych nasion lnu oraz zróżnicowanych dawek witaminy E do modyfikacji składu chemicznego i walorów dietetycznych mięsa wieprzowego [The use of full-fat flax seeds and various vitamin $\mathrm{E}$ doses for modifying the chemical composition and dietetic value of pork]. Zesz. Nauk. Przegl. Hod., 48, 167-174 [in Polish].

Caceres, E., Garcia, M. L., Selgas, M. D. (2008). Effect of pre-emulsified fish oil - as source of PUFA n-3 - on microstructure and sensory properties of mortadella, a Spanish bologna-type sausage. Meat Sci., 80, 183-193.

Coates, W., Ayerza, R. (2009). Chia (Salvia hispanica L.) seed as an n-3fatty acid source for finishing pigs: effects on fatty acid composition and fat stability of the meat and internal fat, growth performance, and meat sensory characteristics. J. Anim. Sci., 87, 3798-804.

Cooper, S. L., Sinclair, L. A., Wilkinson, R. G., Hallett, K. G., Enser, M., Wood, J. D. (2004). Manipulation of the n-3 polyunsaturated fatty acid content of muscle and adipose tissue in lambs. J. Anim. Sci., 82, 1461-1470.

Corino, C., Musella, M., Mourot, J. (2008). Influence of extruded linseed on growth, carcass composition, and meat quality of slaughtered pigs at one hundred ten and one hundred sixty kilograms of live weight. J. Anim. Sci., $86,1850-1860$.

Department of Health (1994). Nutritional Aspects of Cardiovascular Disease. Report on Health and Social Subjects No 46. HMSO, London.

FAO (2008). Food and Nutrition Paper 91. Report of an expert consultation. Fats and fatty acids in human nutrition. 10-14 November 2008, Geneva.

Fiego, D. P. L., Santoro, P., Macchioni, P., Leonibus, E. D. (2005). Influence of genetic type, live weight at slaughter and carcass fatness on fatty acid composition of subcutaneous adipose tissue of raw ham in the heavy pig. Meat. Sci., 69, 107-114.

Folch, J., Lees, M., Stanley, G. H. S. (1957). A simple method for the isolation and purification of total lipids from animal tissue. J. Biol. Chem., 226, 497-509.

Grześkowiak, E., Zając, T., Borzuta, T., Zając, P., Tratwal, Z., Lisiak, D., Strzelecki, J. (2008). Badanie wpływu dodatku do paszy świń preparatu z oleju z nasion lnu na wartość rzeźną tusz oraz jakość mięsa i tłuszczu [Investigations on the effect of the addition to feed of a preparation oil flax on slaughter value carcass meat and fatty quality]. Rocz. Inst. Przem. Mięsn. Tłuszcz., 46, 7-20 [in Polish].

Grześkowiak, E., Borzuta, K., Lisiak, D., Strzelecki, J., Janiszewski, P. (2010). Właściwości fizykochemiczne i sensoryczne oraz skład kwasów tłuszczowych mięśnia Longissimus dorsi mieszańców PBZ $\times$ WBP oraz PBZ $\times(\mathrm{D} \times \mathrm{P})$ [Physical-chemical and sensory properties, as well as composition of fatty acids in Longissimus dorsi muscle of $\mathrm{PBZ} \times \mathrm{WBP}$ and $\mathrm{PBZ} \times(\mathrm{D} \times \mathrm{P})$ pig cross breeds]. Żywn. Nauka Techn. Jakość, 73, 189-198 [in Polish].

Guillevic, M., Kouba, M., Mourot, J. (2009). Effect of a linseed diet or a sunflower diet on performances, fatty acid composition, lipogenic enzyme activities and stearoyl-CoA-desaturase activity in the pig. Livestock Sci., 124, 288-294.

Haak, L., De Smet, S., Fremaut, D., Van Walleghem, K., Raes, K. (2008). Fatty acid profile and oxidative stability of pork as influenced by duration and time of dietary 
linseed or fish oil supplementation. J. Anim. Sci., 86, $1418-1425$.

Hanczakowska, E. (2006). Zastosowanie wytłoków z nasion rzepaku w żywieniu świń [Use of rapeseed cake in pig nutrition]. Wiad. Zootechn., 44, 3, 38-43 [in Polish].

Huang, F. R., Zhan, Z. P., Luo, J., Liu, Z. X., Peng, J. (2008). Duration of dietary linseed feeding affects the intramuscular fat, muscle mass and fatty acid composition in pig muscle. Livestock Sci., 118, 132-139.

Juárez, M., Dugan, M. E. R., Aldai, N., Aalhus, J. L., Patience, J. F., Zijlstra, R. T., Beaulieu, A. D. (2010). Feeding co-extruded flaxseed to pigs: Effects of duration and feeding level on growth performance and backfat fatty acid composition of grower-finisher pigs. Meat Sci., 84, $578-584$.

Kouba, M., Mourot, J. (2011). A review of nutritional effects on fat composition of animal products with special emphasis on n-3 polyunsaturated fatty acid. Biochim., 93, 13-17.

Kowalska, D., Bielański, P., Chełmińska, A. (2011). Wpływ dodatku do paszy oleju lnianego i rybnego na profil kwasów tłuszczowych i utlenienie tłuszczu śródmięśniowego królików [Effect of linseed and fish oil supplements in feed on fatty acid profile and intramuscular fat oxidation in rabbits]. Żywn. Nauka Techn. Jakość, 75, 148-159 [in Polish].

Lisiak, D., Grześkowiak, E., Borzuta, K., Raj, S., Janiszewski, P., Skiba, G. (2013). Effects of supplementary vegetable and animal fats on the slaughter values of fatteners, meat quality, and fatty acid profile in pigs. Czech J. Anim. Sci., 58(11), 497-511.

Lu, P., Zhang, L. Y., Yin, J. D., Everts, A. K. R., Li, D. F. (2008). Effects of soybean oil and linseed oil on fatty acid compositions of muscle lipids and cooked pork flavour. Meat Sci., 80, 910-918.

Ntawubizi, M., Colman, E., Janssens, S., Raes, K., Buys, N., De Smet, S. (2010). Genetic parameters for intramuscular fatty acid composition and metabolism in pigs. J. Anim. Sci., 88, 1286-1294.

Nuernberg, K., Fischer, K., Nuernberg, G., Kuechenmeister, V., Kłosowska, D., Eliminowska-Wenda, G., Fiedler, I., Knder, K. (2005). Effects of dietary olive and linseed oil on lipid composition, meat quality sensory characteristics and muscle structure in pigs. Meat Sci., 70, 63-74.

Peiretti, P. G. (2012). Effects of dietary fatty acids on lipid traits in the muscle and perirenal fat of growing rabbits fed mixed diets. Animals, 2, 55-67.

Pieszka, M. (2007). Effect of vegetable oil supplementation in pig diets on lipid oxidation and formation of oxidized forms of cholesterol in meat. Pol. J. Food Nutr. Sci., 57, 509-506.

Realini, C. E., Duran-Montgé, P., Lizardo, R., Gispert, M., Oliver, M. A., Esteve-Garcia, E. (2010). Effect of source of dietary fat on pig performance, carcass characteristics and carcass fat content, distribution and fatty acid composition. Meat Sci., 85, 606-612.

Sardi, L., Martelli, G., Lambertini, L., Parisini, P., Mordenti, A. (2006). Effects of a dietary supplement of DHA-rich marine algae on Italian heavy pig production parameters. Livestock Sci., 103, 95-103.

Sirri, F., Castellini, C., Bianchi, M., Petracci, M., Meluzzi, A., Franchini, A. (2011). Effect of fast-, medium- and slow-growing strains on meat quality of chickens reared under the organic farming method. Animal, 5, 312-319.

Wachira, A. M., Sinclair, L. A., Wilkinson, R. G., Enser, M., Wood, J. D., Fisher, A. V. (2002). Effects of dietary fat source and breed on the carcass composition, n-3 polyunsaturated fatty acid and conjugated linoleic acid content of sheep meat and adipose tissue. Br. J. Nutr., 88, 697-709.

Więcek, J., Rekiel, A., Batorska, M., Skomiał, J. (2011). Effect of restricted feeding and realimentation periods on pork quality and fatty acid profile of M. longissimusthoracis. Meat Sci., 87, 244-249. 


\section{WARTOŚĆ ODŻYWCZA SUROWEGO MIĘSA WIEPRZOWEGO W ZALEŻNOŚCI OD RODZAJU TŁUSZCZU STOSOWANEGO W PASZY TUCZNIKÓW}

\section{STRESZCZENIE}

Wstęp. Celem pracy była ocena wartości odżywczej mięsa wieprzowego pozyskanego od tuczników żywionych paszą różniącą się rodzajem zastosowanego tłuszczu.

Materiał i metody. Mięso pozyskiwano od świń żywionych w czterech grupach doświadczalnych. W grupach A i B źródłem tłuszczu była mieszanina olejów rzepakowego i lnianego w układzie 1:2,5 lub 2,3:1:0,2. W grupie $\mathrm{C}$ podawano zwierzętom mieszaninę oleju rzepakowego (1 część), rybiego (2 części) oraz smalcu (0,5 części). Grupa D otrzymywała mieszaninę oleju lnianego w ilości jak w grupie B (2,5 części), ale podawanego łącznie z olejem rybim (tran z dorsza; 1 część). Próbki pobranego mięsa poddawano analizom chemicznym w celu określenia podstawowej wartości odżywczej. Zawartość wody (suchej masy), białka, tłuszczu i składników mineralnych ogółem, wyrażonych jako popiół, oznaczano metodami według AOAC. Zawartość węglowodanów wyliczano z różnicy. Profil i zawartość kwasów tłuszczowych w mięsie oznaczano, stosując metodę Folcha (estry metylowe kwasów tłuszczowych). Rozdział prowadzono z wykorzystaniem chromatografii gazowej GC, THERMO wyposażonej w kolumnę kapilarną RT 2560 RESTEC (100 m $\times 0,25 \mathrm{~mm} \times 0,2 \mu \mathrm{m}) \mathrm{z}$ użyciem helu jako gazu nośnego.

Wyniki. Modyfikacja źródła tłuszczu w paszy tuczników nie wpłynęła na zawartość białka i składników mineralnych ogółem wyrażonych jako popiół, natomiast istotnie wpłynęła na zawartość tłuszczu i wody. Stwierdzono, że stosowanie różnych typów tłuszczu w paszy tuczników przyczyniło się do otrzymywania mięsa o zmodyfikowanym profilu kwasów tłuszczowych. Większą zawartość kwasów tłuszczowych typu n-3 obserwowano w grupach B i D (otrzymujących mieszaninę olejów z przewagą oleju lnianego). Tłuszcz mięsa z tych grup zawierał mniej kwasów tłuszczowych n-6 i n-9, co wpływało korzystnie na wskaźnik jakości tłuszczu wyrażony stosunkiem n-6/n-3. Mięso zwierząt z tych grup zawierało mniej kwasów MUFA, przy porównywalnych zawartościach kwasów UFA i SFA. Mięso zwierząt wszystkich grup doświadczalnych charakteryzowało się także zbliżonym wzajemnym udziałem ogólnej zawartości PUFA:SFA wynoszącym $0,5-0,6$.

Wnioski. Modyfikacja źródła tłuszczu w paszy tuczników nie wpłynęła na zawartość białka i składników mineralnych ogółem wyrażonych jako popiół, natomiast wpływała istotnie na zawartość tłuszczu i wody. Różne źródło tłuszczu w paszy tuczników nie miało wpływu na wartość energetyczną oraz zawartość w mięsie kwasów tłuszczowych nasyconych (SFA) oraz nienasyconych UFA, natomiast istotnie wpływało na udział poszczególnych kwasów tłuszczowych należących do grup jednonienasyconych (MUFA) oraz n-3 i n-6.

Słowa kluczowe: mięso wieprzowe, wartość odżywcza, rodzaj tłuszczu w paszy świń

For citation - Do cytowania

Waszkiewicz-Robak, B., Szterk, A., Rogalski, M., Rambuszek, M., Kruk, M., Rokowska, E. (2015). Nutritional value of raw pork depending on the fat type contents in pigs feed. Acta Sci. Pol. Technol. Aliment., 14(2), 153-163. DOI: 10.17306/J.AFS.2015.2.17 